for a reduced final height attainment will be determined and assessed early. Treatment with human GH should be started as soon as possible to obtain satisfactory results. In our patient there was a delay in the institution of investigations. If bone age is advanced at the time of treatment the chance of great benefit is slight.

A W Burrows

T D R HOCKADAY

Radcliffe Infirmary,
Oxford

Shalet, S M, et al, Clinical Endocrinology, 1976, 5, 287. 2 Shalet, S M, et al, Lancet, 1975, 2, 104.

Harrop, J S, et al, Clinical Endocrinology, 1976, 5, 313. Tanner, J M, et al, Archives of Disease in Childhood,
1966, 41, 454.

\section{Lithium and thyrotoxicosis}

SIR,-In my letter (17 September, p 765) commenting on the statement in your leading article (6 August, p 346) that "there is at least one report of lithium-induced thyrotoxicosis"1 I omitted to state that there had been other reports of thyrotoxicosis in patients on longterm lithium therapy for manic-depressive illness. ${ }^{2-5}$

West Park Hospital,

Epsom, Surrey

' Franklin, L M, New Zealand Medical fournal, 1974, 79, 782 .

${ }^{2}$ Cubitt, T, Lancet, 1976, 1, 1247

Bufaqueer, H H, and Myers, D H, New Zealand Medical fournal, 1974, 79, 1409

- Rosser, R, British fournal of Psychiatry, 1976, 128, 61.

Brownlie, B E W, et al, Australian
fournal of Medicine, 1976, 6, 223.

\section{Increased incidence of poliomyelitis}

SIR,-In a previous letter (Drs J Nagington and D Rubenstein, 26 February, p 573) attention was drawn to the increased incidence of paralytic poliomyelitis in Britain at the end of 1976. A clearer picture of the change has now emerged.

Up to the end of July this year there have been 13 cases of confirmed paralytic poliomyelitis compared with four in the same period the previous year. It is noteworthy that all 13 were in children aged 7 years or under - that is, a return to "infantile paralysis." Ten of the 13 were caused by type 1 virus, two by type 2 , and one by type 3 , and not a single patient had received any polio vaccine at any time. Since all but two were over 6 months of age vaccine, if given, should have protected 11 of them.

It is evident that there is need to intensify efforts to achieve the maximum possible vaccination of children under 5 years of age.

J NAGINGTON

Public Health Laboratory Service,

Addenbrooke's Hospital,

Hills Road,

Susan E J Young

Communicable Disease Surveillance

Lentre,

\section{Dextrostix/Eyetone in the insulin hypoglycaemia test}

SIR,-An acceptable method of monitoring insulin tolerance tests would enhance both their efficiency and their safety by ensuring adequate but not dangerous hypoglycaemia. The Dextrostix/Eyetone system as proposed by $\operatorname{Dr} M$ A Preece and $M r R G$ Newall (16 July, p 152) is "tantalisingly close" to an adequate monitor, as Dr A M Bold and others point out (13 August, p 459). We feel that this system has a place in monitoring hypoglycaemia provided its limitations are recognised and certain practical procedures observed.

Even though venous blood gives more reliable results than capillary blood, we found that Dextrostix/Eyetone systematically overestimated venous plasma glucose concentrations less than $3.3 \mathrm{mmol} / 1(60 \mathrm{mg} / 100 \mathrm{ml})$. The discrepancy was greatest with the lowest plasma glucose concentrations. Clinical features of hypoglycaemia should not be ignored because of reassuring Dextrostix readings both because of this bias and also because of occasional incorrect high Dextrostix values. Although venous Dextrostix/Eyetone and conventional determinations correlate reasonably, the correlation for capillary blood is not as good. Moreover, if the finger is pricked when still wet from the alcohol preparation dangerously misleading results can occur (for example, $12.2 \mathrm{mmol} / 1(220 \mathrm{mg} / 100 \mathrm{ml})$ instead of $2.3 \mathrm{mmol} / 1(41.5 \mathrm{mg} / 100 \mathrm{ml})) .^{1}$

The Dextrostix/Eyetone system should be set up correctly. The two-point calibration system described by $\mathrm{Dr}$ Preece and $\mathrm{Mr}$ Newall is inadequate, as is their method of detecting deteriorated Dextrostix. The following simple operating procedure is accepted by nursing staff and gives reasonable precision (coefficient of variation $5.4 \%$ at $2.5 \mathrm{mmol} / 1$ (45 mg/100 ml)).

(1) Turn on the Eyetone $30 \mathrm{~min}$ before use.

(2) At the beginning of each week set the reflectance strips with the adjustment screws, making sure the white line on the thumbwheel is in the middle of the visible region.

(3) Set up calibration standard to $7.2 \mathrm{mmol} / \mathrm{l}$ (130 $\mathrm{mg} / 100 \mathrm{ml}$ ) with the thumbwheel, following the instructions supplied by Ames for use of Dextrostix.

(4) Check the machine calibration by testing one of the three Tek-Chek controls. These should read $2 \cdot 5,5 \cdot 0$, and $13.9 \mathrm{mmol} / 1(45,90$, and $250 \mathrm{mg} /$ $100 \mathrm{ml}) \pm 10 \%$ respectively.

This procedure is repeated weekly. In between the machine is left on continuously and steps 3 and 4 carried out whenever the Eyetone has not been used for two or more hours or if there is a change of operator.

R White

P J PHILLIPS $R$ W PAIN

Division of Clinical Chemistry,

Institute of Medical and

Adelaide

S Australia

' Phillips, P J, et al, Medical fournal of Australia, 1977, Bali, $\mathrm{S}$ G, and Hughes, A S B, British Medical fournal, 1976, 1, 1279.

\section{A tennis elbow support}

SIR,-Tennis elbow is a painful condition and stops an otherwise active and healthy adult from taking part in sports or even from pursuing his work. In most cases a local steroid injection will effect a "cure," but any return to strenuous activity like tennis or gardening can cause a relapse of the tennis elbow.

I suffer from tennis elbow myself. I am also rather interested in tennis. Last summer, after two local steroid injections with only temporary relief, I found that a handkerchief tied around the forearm just below the elbow enabled me to play tennis and yet did not restrict the movements of my elbow. I followed this idea up and got a surgical appliance firm to make a tennis elbow support which would grip the upper part of the forearm without interfering either with the elbow joint or with the blood circulation of the limb. The material used was a special type of rubber with surface cross-striations and was fairly rigid when stretched. This was held together by Velcro fastening. The exact specifications were: white calendered rubber gauge $40 / 1000$, width $2 \frac{1}{2}$ in $(5.25 \mathrm{~cm})$, length 13 in $(33 \mathrm{~cm})$, with twin Velcro fastening 4 in $(10 \mathrm{~cm})$ long giving a 3 -in $(7.5 \mathrm{~cm})$ adjustment.

The tennis elbow support is placed around the upper part of the forearm just below the head of the radius. This anatomical landmark is easily identified by palpation. The forearm muscles are relaxed and the support applied without stretching on to the bare forearm. The special texture of the rubber ensures that it does not slip. Sweat holds it more firmly in place. When the patient grips anything, as during the act of holding a tennis racket, the forearm muscles contract and are supported near the attachment to the epicondyles of the humerus. This support is sufficient to ease the symptoms of tennis elbow. It can be worn the whole day or during any strenuous activity, It has been used on occasions in cases of golfer's elbow.

As the preliminary results are encouraging I thought it would be useful to publish this. Fifty of these prototype tennis elbow supports were initially supplied by $M$ Masters and Sons Ltd, of London. Within three months another 100 supports were made available for trial use. Seventy-five of these supports have been used by patients in the Enfield district who have had recurrence of their symptoms. Fifty of these patients were personally reviewed by me; $46(92 \%)$ have been helped by the tennis elbow support, having had less pain and being able to carry out most of their activities without any symptoms. They are able to play sports like tennis and squash.

I feel the preliminary results are encouraging enough for any surgeon interested in the condition of tennis elbow to try these supports in patients with recurrent symptoms. Their use might well reduce the number of patients having surgery for resistant tennis elbow.

\section{S C CHEN}

Enfield District Hospital,
Enfield, Middx

\section{Neonatal electrocardiogram and cot} deaths

SIR,-With reference to the articles by $\mathrm{Dr}$ B R Keeton and others (3 September, p 600), I would like to report a case of actual cot death which, in retrospect, may have been caused by cardiac arrhythmia.

A female infant was delivered by emergency lower-segment caesarean section because of fulminant pre-eclampsia. The Apgar score at $1 \mathrm{~min}$ was one and the baby required intubation and positive pressure respiration for $10 \mathrm{~min}$. On examination the gestational age was 36 weeks by the Dubowitz criteria and she was small for dates, weighing $1.28 \mathrm{~kg}$. In spite of these problems her initial progress was satisfactory apart from excessive crying which required sedation with chloral.

On the evening of her 29th day she was found 